\title{
Teller test with functional vision evaluation in children with low vision
}

\author{
Teste com Cartões de Teller e avaliação \\ da visão funcional em crianças com baixa visão
}

Anita Zimmermann¹, Sarah Vieira da Silva² , Sara Martins Vieira Zimmermann¹, Rodrigo Pessoa Cavalcanti Lira ${ }^{1}$, Keila Miriam Monteiro de Carvalho ${ }^{1}$

\begin{abstract}
Objective: To know the effectiveness of Teller card test along with the functional vision evaluation in low vision preschool children presenting normal or delayed development. Methods: Transversal study comprising patients from the children visual stimulation Ambulatory Service of the Faculty of Medical Sciences, University of Campinas Teaching Hospital, Campinas (SP)(FCM/HC/Unicamp). The best corrected visual acuity was obtained using Teller cards and functional vision evaluation, independent from the child development. Results: From a total of 143 evaluated children, 65\% did not respond to the Teller card test, only to, the functional vision evaluation. Among 143 children, 99 (70\%) presented development delay and 44 (30\%), normal development. Conclusion: The Teller card test was not enough to evaluate the children visual acuity with development delays, since more than half of them were not responsive to it, making it necessary that they were submitted to a complementary functional visual evaluation.
\end{abstract}

Keywords: Visual acuity; Low vision; Vision; Child development; Vision disorders

\section{ResUMO}

Objetivo: Conhecer a eficácia do teste com Cartões de Teller em complemento a avaliação da visão funcional em crianças préescolares com baixa visão e desenvolvimento normal ou atrasado. Métodos: Estudo transversal em pacientes do ambulatório de estimulação visual infantil do Hospital de Clínicas da Faculdade de Ciências Médicas da Universidade Estadual de Campinas (HC/ FCM/Unicamp). A acuidade visual com a melhor correção óptica foi medida com Cartões de Teller e avaliação da visão funcional, independente do desenvolvimento da criança. Resultados: De um total de 143 crianças avaliadas $65 \%$ não responderam ao teste de Teller, porém, em complemento à avaliação da visão funcional pôde ser conhecida a acuidade visual das mesmas. Dentre as 143 crianças, 99 (70\%) apresentaram atraso no desenvolvimento e 44 (30\%) desenvolvimento normal. Conclusão: O Teste com Cartões de Teller para se conhecer a acuidade visual de crianças com atraso em seu desenvolvimento não se apresentou suficiente, pois mais da metade das crianças avaliadas não foi responsiva ao mesmo, necessitando de complementação de avaliação da visão funcional para a medida da acuidade visual.

Descritores: Acuidade visual; Baixa visão; Visão; Desenvolvimento infantil; Transtornos da visão

\footnotetext{
'Universidade Estadual de Campinas (SP), Brazil;

${ }^{2}$ Ophthalmological Doctor - Cascais, Portugal.
}

The authors declare no conflict of interest.

Recebido para publicação em 08/04/2015 - Aceito para publicação em 11/07/2015 


\section{INTRODUCTION}

$\mathbf{T}$ Veller card test - visual acuity test - is being applied in preschool children presenting committed development or not, for measuring their angular visual acuity ${ }^{(1)}$. Patterned for the evaluation of visual acuity in babies, starting from approximately 1 month old, it can be used until the age needed for children with development delays, with or without associated comorbidities or deficiencies ${ }^{(1,2)}$.

Children with development delays can present neuroperceptive and cognitive difficulties to respond to ophthalmological tests; therefore, psicophysical tests should be provided to them, with the children cooperation and colaboration for the establishment of assertive diagnoses and conducts.

The best functional vision is one of the main objectives of the ophthalmological service. This represents a big challenge in the ophthalmological area $^{(3),}$ once the comprehension of the visual infant behavior is necessary.

Functional vision is a relatively new concept ${ }^{(4)}$, meaning visual capacity on its potentialities. Once vision is a learned function, with its possible qualities to be developed, mainly during the first months of life, when the plasticity of the nervous system is maximum ${ }^{(5)}$, it is interesting for children to be offered situations with visual stimulation, so they can have the opportunity to develop themselves ${ }^{(6-8)}$.

The functional vision evaluation, as a psychophysical test, is based on the observation of the child spontaneous behavior in ambulatory environments, where the observer presents and suggests evaluative activities. The observer/evaluator, with the knowledge of the infant visual development, interprets their visual behavior ${ }^{(9-12)}$.

Regarding vision evaluative conditions, the child cognitive capabilities should be considered, so specific incentives can be interpreted ${ }^{(13)}$. Children with development delay may take longer to answer or make it difficult for the evaluator to observe their visual responses.
This study aimed to evaluate the effectiveness of the visual acuity measurement, using the Teller card test along with the functional vision evaluation in children with low vision, with a committed development or not.

\section{Methods}

This is a transversal study developed during the period from december 2010 to june 2012, at the Children Visual Stimulation Ambulatory Service of the Unicamp Teaching Hospital, approved by the Research Ethics Committee under number 1025/2010.

The total sample comprised 143 children with low vision, of which $78(55 \%)$ were male. There was an age variation between zero months old and 5 years and 11 months old, according to their scheduling in the ambulatory service, with no sampling or random selection of cases, having as inclusion criteria the age group mentioned above and the consent term signed by the responsible for the child. The exclusion criterion was total blindness.

The visual acuity was measured using the best optical correction, in a photopic environment, with natural light, separated eyes, by a pedagogue professional, specialized in visual disability and infant visual stimulation, using Teller cards with 38 centimeters of distance. In some cases, it was necessary for the cards to be nearer, according to what is established in the test manual. In the case of unsatisfactory responses, the test was repeated in another occasion.

In complementation to the Teller card test, the functional vision evaluation (table 1) was applied. The information about the children development was obtained from their hospital documentation. Patients with committed development were followed by the neurological pediatric team of the same hospital.

Table 1

Data Gathering for the Children Functional Vision Evaluation
$\underline{\text { Age }}$
( ) $0-5$ months old
( ) 6 months -11 months old
( ) 1 year -1 year 11 months old
( ) 2 years -3 years 11 months old
( ) 4 years -5 years 11 months old

\section{Development}

( ) Normal development

( ) Development delay

(1) Light Perception (PL): $\mathrm{m}(2.0)$

$0-50 \mathrm{~cm}=0.0 / 50 \mathrm{~cm}-1 \mathrm{~m}=0.5 / 1 \mathrm{~m}-2 \mathrm{~m}=1.0 / 2 m-3 m=2.0$

( ) With tracking (2.0)

( ) Without tracking (0.0)

( ) Environment with artificial light (1.0)

( ) Environment with low light (0.0)

( ) Does not present (0.0)

(2) People Perception:

$0-50 \mathrm{~cm}=0.0 / 50 \mathrm{~cm}-1 \mathrm{~m}=\overline{0.5 / 1 m-2} \mathrm{~m}=1.0 / 2 \mathrm{~m}-3 \mathrm{~m}=2.0$

( ) With tracking (2.0)

( ) Without tracking $(0.0)$

( ) Does not present (0.0)
(3) Visual Fixation

( ) Central (4.0)

( ) Temporal (1.0)

( ) Does not present (0.0)

(4) Nystagmus

( ) Moderated (1.0)

( ) Intense $(0.0)$

() Does not present (4.0)

(5) Object perception: $\mathrm{m}(1.0)$

$0-50 \mathrm{~cm}=0.0 / 50 \mathrm{~cm}-1 \mathrm{~m}=0.5 / 1 \mathrm{~m}-2 \mathrm{~m}=0.5 / 2 m-3 m=1.0$

( ) Does not present (0.0)

( ) Only backlighted objects:

$0-50 \mathrm{~cm}=0.0 / 50 \mathrm{~cm}-1 \mathrm{~m}=0.5 / \overline{1 m-2 m=0.5}$

( ) With tracking $(0.5)$

() Without tracking (0.0)

( ) With a 5-cm diameter (1.0)

() With a $10-\mathrm{cm}$ diameter $(0,5)$

( ) Visual motor coordination (1.0)

( ) Tridimentional visual response (0.5)

(6) Color Perception

( ) Recognizes colors (5.0)

() Does not recognize colors $(0,0)$

Teller cards:

Right eye:

Left eye:

( ) NR - Nonresponsives (0.0) 


\section{Results}

From the total 143 studied children, 92 (65\%) were not responsive to the Teller card test. Regarding their development, $44(30 \%)$ presented normal development, and $99(70 \%)$, development delays.

The responsiveness to the Teller card test ranged according to the child development, described in table 2.

Table 2

\section{Responsiveness to the Teller card test $\mathrm{x}$ Development}

Responsiveness Normal neurological Neurodevelopment Total to the test development delay

Teller cards $\quad 44(30 \%) \quad 99(70 \%)$

Responsive $\quad 31(70 \%) \quad 20(20 \%) \quad 51(36 \%)$

Non-responsive $13(30 \%) \quad 79(80 \%) \quad 92(65 \%)$

$\begin{array}{llll}\text { Total } & 44 & 99 & 143(100 \%)\end{array}$

From the 44 children with normal development, 31 (70.4\%) responded to the Teller card test. From the 99 with development delay, only $20(20.2 \%)$ were responsive to the Teller card test.

The visual functional evaluation was held as a complement to the Teller card test, creating a special score, in a graduation of score 0 to 5.0 for each topic from the vision functional evaluation.

It was considered score above or equal 18, high intensity punctuation, and the visual stimulation was not considered necessary. Score below 18, with low intensity, the visual stimulation was indicated, oriented and followed by an able pedagogue professional (table 3).

\section{Discussion}

In this population, there was a significant prevalence of development delay cases, with comorbidities, cerebral damage sequels, with or without other associated deficiencies, low responsiveness to the Teller card test, with little collaborative behaviors, making it necessary the use of the complementary functional vision evaluation, as presented in other studies $(14,15)$.

After being submitted to the Teller card test and functional vision evaluation, 105 children, representing $74 \%$ from the total, have received indication for visual stimulation.

Considering these data, it was observed that the functional vision evaluation, as a complement of the Teller card test, can orientate visual therapeutic conducts, being understood that the earlier the visual stimulation intervention is, the better the possibilities of visual development are going to be for each age group researched in this study.

The cognitive, neurological and motor compromise, as well as the difficulty in comprehending the child visual behavior by the evaluator, restraining the communication and interpretation of visual responses, were also observed by other researchers ${ }^{(6,16)}$ in their studies with children in the same age group received in similar environments.

Visual responses are individual processes and the visual improvement depends on the vision integrity ${ }^{(17)}$. During the child development, vision promotes their social and environmental integration; while vision decrease or its non-existence reduces the child capacities to develop themselves in other sensorial aspects, which may affect their psychological, physical, emotional and social behavior ${ }^{(16,18-22)}$.

Some authors present the Teller card test as a good option to evaluate the visual acuity of children with development delay $(1,6,23-26)$. However, it was observed in this study that using such a test alone was not enough, since more than half of the children were not responsive to it, making it necessary that they were submitted to a complementary psychophysical test.

According to other studies ${ }^{(6,16)}$, there is a wide difficulty in defining the visual compromise or incapacity of these children for their cognitive, neurological or motor limitations, as well as for the difficulty they have in communicating their visual responses, making it difficult the understanding by the involved ophthalmologists and therapeutic professionals.

Table 3

Result from the vision functional evaluation from the studied group $(n=143)$

\begin{tabular}{|c|c|c|c|c|c|c|c|c|}
\hline Score & Intensity & $\begin{array}{l}0 \text { months } \\
5 \text { months } \\
2 \text { children }\end{array}$ & $\begin{array}{l}6 \text { months } \\
11 \text { months } \\
7 \text { children }\end{array}$ & $\begin{array}{l}1 \text { year - } 1 \text { year } \\
\text { and } 11 \text { months } \\
32 \text { children }\end{array}$ & $\begin{array}{l}2 \text { years }-3 \text { years } \\
\text { and } 11 \text { months } \\
51 \text { children }\end{array}$ & $\begin{array}{l}4 \text { years }-5 \text { years } \\
\text { and } 11 \text { months } \\
51 \text { children }\end{array}$ & $\begin{array}{c}\text { Normal } \\
\text { Development }\end{array}$ & $\begin{array}{c}\text { Development } \\
\text { Delay }\end{array}$ \\
\hline $\begin{array}{r}\text { Higher or } \\
\text { Equal to } 18\end{array}$ & $\begin{array}{ll}\mathbf{r} & \\
8 & \text { High }\end{array}$ & & $\begin{array}{l}1 \text { Normal } \\
\text { development } \\
1 \text { Development } \\
\text { delay }\end{array}$ & $\begin{array}{l}1 \text { Normal } \\
\text { development } \\
5 \text { Development } \\
\text { delay }\end{array}$ & $\begin{array}{l}7 \text { Normal } \\
\text { development } \\
3 \text { Development } \\
\text { delay }\end{array}$ & $\begin{array}{c}6 \text { Normal } \\
\text { development } \\
14 \text { Development } \\
\text { delay }\end{array}$ & 15 & 23 \\
\hline $\begin{array}{l}\text { Score } \\
\text { Below } 18\end{array}$ & Low & $\begin{array}{l}1 \text { Normal } \\
\text { development } \\
1 \text { Development } \\
\text { delay }\end{array}$ & $\begin{array}{l}1 \text { Normal } \\
\text { development } \\
\text { 4 Development } \\
\text { delay }\end{array}$ & $\begin{array}{l}6 \text { Normal } \\
\text { development } \\
20 \text { Development } \\
\text { delay }\end{array}$ & $\begin{array}{l}12 \text { Normal } \\
\text { development } \\
29 \text { Development } \\
\text { delay }\end{array}$ & $\begin{array}{c}9 \text { Normal } \\
\text { development } \\
22 \text { Development } \\
\text { delay }\end{array}$ & 29 & 76 \\
\hline $\begin{array}{l}\text { Visual } \\
\text { Stimulation } \\
\text { Suggestion }\end{array}$ & & 2 & 5 & 26 & 41 & 31 & & \\
\hline
\end{tabular}


Sometimes, for a better diagnostic acumen, the follow-up of electrophysiological evaluation in children becomes necessary ${ }^{(27)}$

Furthermore, considering the aspects of the infant development as a way of knowing the expected behaviors for each age group, ophthalmological services are suggested to infants, aiming to broaden the comprehension of the expressions in the evaluated child and their responses to psychophysical tests.

Another interesting aspect to be observed is that, when it comes to children, the ludic must be explored, so the child feels comfortable and collaborative during tests and evaluations, as well as in visual stimulation follow-ups.

\section{AUTHOR CONTRIBUTIONS}

Zimmermann, A; Silva SV; Zimmermann, S; Lira PCR and Carvalho MM designed the work, interpreted the data, drafted the manuscript, provided final approval of the version to be published and agreed to be accountable for all aspects of the work.

\section{ACKNOWLEDGEMENTS}

To ophthalmologists: Augusto Duarte, John Paul Fernandes Felix and Rafael Marcicano Cezar Vieira for valuable contributions during this study.

\section{REFERENCES}

1. Teller DY, Dobson V, Mayer DL, Candy TR. Teller Acuity Cards II -handbook. Rev Ed. Chicago: Stereo Optical Company; 2009.

2. Mateos JG, Jimenez RM, Luengo IC. El Vap-Cap: una herramienta útil para la valoración del funcionamiento visual en bebés y niños com polidiscapacidad. Integración: Rev Sobre Descapacidad Visual. 2010; 58. [Internet]. [citado 2015 Jun 6]. Disponível en: http://www.once.es/new/servicios-especializados-en-discapacidadvisual/publicaciones-sobre-discapacidad-visual/nueva-estructurarevista-integracion/copy_of_numeros-publicados/numero-58/ copy17_of_asesoramiento-y-apoyo-a-la-familia-en-el-proceso

3. El Byoumi BM, Mousa A. Visual function of egyptian children with Low Vision and the demographic determinants. Middle East Afr J Ophthalmol. 2010; 17(1):78-82.

4. Bishop VE. Making choices in functional vision evaluations: noodles, needles and haystacks. J Vis Impairm Blind.1998; 82(3):94-9.

5. Tabuse MK, Cronemberger MF. Alterações oftalmológicas em crianças com paralisia cerebral. In: Samapaio MW, organizador. Baixa visão e cegueira: os caminhos para a reabilitação, a educação e a inclusão. Rio de Janeiro: Cultural Médica: Guanabara Koogan; 2010.

6. Rossi LD, Vasconcelos GC, Saliba GR, Magalhães LC, Soares AM, Cordeiro SS, Amorim RH. Avaliação da visão funcional para crianças com baixa visão de dois a seis anos de idade - estudo comparativo. Arq Bras Oftalmol. 2011;74 (4):262-6.

7. Colenbr A. Colebrand: Aspect of visual loss - Visual functions and functional vision. This paper is based on a draft for the paper that appeared in: Vis Impairment Res. 2003; 5(3) [Papers presented at the Conference on "Functional Vision - Assessment and Outcomes]

8. Droste PJ, Archer SM, Helveston EM. Measurement of low vision in children and infants. Ophthalmology. 1991;98(10):1513-8.

9. Lindstedt E. O quanto uma criança vê? Guia para profissionais especializados em crianças deficientes visuais. traduzido por: Silvia Veitzman. São Paulo: Centro Gráfico SSP: s.d.
10. Dantas RA. Validação de Escala Optométrica de Figuras [tese]. Fortaleza: Universidade Federal do Ceará; 2006.

11. Leonhardt M. El bebé ciego: Primera atención - un enfoque psicopedagógico. Barcelona: Masson; 1992. p.162.

12. Chou HY. A avaliação funcional da visão do escolar com baixa visão. In: Baixa visão e cegueira: os caminhos para a reabilitação, a educação e a inclusão.Samapaio MW, organizador. Rio de Janeiro: Cultura Médica: Guanabara Koogan: 2010.

13. Clinic Practice Guideline, Quick Reference Guide for parents and professionals. Vision Impairment: Assessment and Intervention for young children (Age 0-3). New York: New York State Department of Health Division of Family Health Bureau of Early; 2007.

14. Souza GL, Kantorski LP. Maus tratos na infância [ Child abuse in childhood]. Fam Saúde Desenvol. 2003. 5(3):213-22.

15. Haddad MA, Seib M, Mateus KR, Aleixo R, Sampaio MW, KaraJosé N. Low vision and blindness in children with multiple handicaps. Int Congress Serie. 2005; (1282):397-401. [Proceedings of the International Congress held between 4 and 7 April 2005 in London, UK].

16. Souza TA, Souza VE, Lopes MC, Kitadal SP. [Description of the neuropsychomotor and visual development of visually impaired children]. Arq Bras Oftalmol. 2010; 73(6):526-30. Portuguese.

17. Decker CA. Children: the early years. Illinois: The GoodheartWillcox; 1988.

18. Willrich A, Azevedo CC, Fernandes JO. Desenvolvimento motor na infância: influência dos fatores de risco e programas de intervenção. Rev Neurocienc. 2009;17(1):51-6.

19. Miranda LP, Resegue R, Figueiras AC. A criança e o adolescente com problemas do desenvolvimento no ambulatório de pediatria. J Pediatr. 2003; 79 (1):33-42.

20. Lindstedt E. Abordagem clínica de crianças com baixa visão. In: Veitzman S. Visão subnormal. São Paulo: Cultura Médica: 2000. p. 192.

21. Gagliardo HGRG. Avaliação de funções visomotoras em lactentes a termo pequenos para a idade gestacional no primeiro semestre de vida. [tese] Campinas: UNICAMP; 2003.

22. Ruas TC. Avaliação do comportamento visomotor de lactentes nascidos pré-termo durante o primeiro trimestre de vida: medida para proteção da saúde ocular [tese]. São Carlos: Universidade Federal de São Carlos; 2006.

23. Dutton GN, McKillop EC, Saidkasimova S. Visual problems as a result of brain damage in children. $\mathrm{Br} \mathrm{J}$ Ophthalmol. 2006;90(8):932-3.

24. Salomão SR, Ejzenbaum F, Berezovsky A, Sacai PY, Pereira JM. Age norms for monocular grating acuity measured by sweepVEP in the first three years of age. Arq Bras Oftalmol. 2008; 71(4):475-9.

25. Salomão SR, Ventura DF. Large sample population age norms for visual acuities obtained with Vistech-Teller Acuity Cards. Invest Ophthalmol Vis Sci. 1995;36(3):657-70.

26. Kronbauer AL, Schor P, Carvalho LAV. Medida da visão e testes psicofísicos. Arq Bras Otalmol. 2008; 71(1):122-7.

27. Coelho AC, Marta DC, Dias MA, Salvador M, Reis VN, Pacheco ZM. Olho vivo: analisando a acuidade visual das crianças e o emprego do lúdico no cuidado de enfermagem. Esc Anna Nery Rev Enferm. 2010;14(2):318-23.

\section{Corresponding author:}

Anita Zimmermann

Universidade Estadual de Campinas

Street Antônio Luis Carbone, 78

Zip code: 13.083-050 - Campinas (SP), Brazil

Phone: 55-19-997416468

E-mail: anitasdz@gmail.com 